\title{
Differences of genetic variation based on isozymes of primary and secondary metabolism in Quercus petraea *
}

\author{
A Zanetto, A Kremer, T Labbé \\ INRA, laboratoire de génétique et d'amélioration des arbres forestiers, \\ BP 45, 33611 Gazinet Cedex, France
}

\begin{abstract}
Summary - The genetic variation among 18 populations of $Q$ petraea was investigated, by studying the variability of 6 enzyme-coding loci. The populations were distributed over the range of the species. Three of the enzymes studied are involved in the primary metabolism (group I), while the remaining 3 are part of the secondary metabolism (group II). With respect to enzymes of group I, populations from the western part of the range showed higher observed and expected heterozygosities than eastern and extreme southern populations. Differentiation among populations was low; $G_{\mathrm{st}}$ values varied between 2 and $5 \%$ depending upon the locus investigated. Based upon enzymes of group I, differentiation among populations of the central part of the range was of the same magnitude as that among populations of the total range for enzymes of group I. However, levels of differentiation increased for enzymes of group II.
\end{abstract}

allozyme / heterozygosity / genetic differentiation / $Q$ petraea

Résumé - Variabilité génétique des enzymes du métabolisme primaire et secondaire chez le chêne sessile. La variabilité génétique de Quercus petraea a été étudiée sur un échantillon de 18 populations venant de l'ensemble de l'aire naturelle. L'analyse portait sur 6 locus correspondant à 6 enzymes, dont 3 étaient impliquées dans le métabolisme primaire (groupe I) et les 3 autres dans le métabolisme secondaire (groupe II). Les populations occidentales sont plus variables (hétérozygotie observée et théorique) que les populations orientales ou de l'extrémité méridionale de l'aire de distribution. Ces résultats ne s'appliquent qu'aux enzymes du groupe 1. La différenciation entre populations reste très faible; les valeurs de $\mathrm{G}_{s t}$ varient de 2 à $5 \%$ selon les enzymes. Pour les enzymes du groupe $I$, la différenciation entre les populations du centre de l'aire de distribution est du même ordre de grandeur que celle entre les populations de l'ensemble de l'aire. Par contre, dans le cas des enzymes du groupe II la différenciation augmente avec la taille de l'échantillon des populations.

\section{allozyme / hétérozygotie / différenciation génétique / Q petraea}

\footnotetext{
* The research has been supported by a EEC grant MA1B/009-0016, 0037-0038 'Genetics and breeding of oaks'.
} 


\section{INTRODUCTION}

The natural range of sessile oak (Quercus petraea (Matt) Liebl) extends over the entire continent of Europe, with the exception of the Mediterranean region and northern Scandinavia (Camus, 1934-1954). Partial information on geographic variation of the species is based on regional provenance trials (Krahl-Urban, 1959; Kleinschmit, 1993). Allozyme variation studies have only recently been started and have also been limited to a regional scale (in Germany, Müller-Starck and Ziehe, 1991; in France, Zanetto, 1989; Kremer et al, 1991). These have shown that sessile oak exhibits high levels of within-stand gene diversity compared to other forest species. However, differentiation among stands, within the frame of the population sample, is extremely low. Similar results have been found in other oak species with wide distribution ranges (Quercus macrocarpa, Schnabel and Hamrick, 1990; Quercus ilex, Lumaret and Michaud, 1991).

Allozymes studied in population surveys usually correspond to enzymes involved in primary and secondary metabolism. The objective of this study was to evaluate levels of within-population variation and genetic differentiation between populations over the range of the species. Special attention has been given to the comparison of gene diversity statistics between the 2 classes of enzymes.

\section{MATERIALS AND METHODS}

Eighteen populations were sampled over the natural range (fig 1). This is part of a range-wide study on gene diversity of $Q$ petraea. Seeds were collected in each stand on the basis of a systematic grid system comprised of 30-50 collection points. Seeds were collected 100-200 at each point and bulked for future establishment of provenance trials. The area investigated within each stand varied between 15 and 20 ha. A random sample of 120 acorns was taken from each bulked seed lot and used for further analysis by electrophoresis.

Acorns were soaked in water for $24 \mathrm{~h}$ and germinated on vermiculite in an incubator. When the radicle was $2-4 \mathrm{~cm}$ long, enzymes were extracted from the radicle tissue by means of a $0.1 \mathrm{M}$ Tris$\mathrm{HCl}$ buffer, $\mathrm{pH} 8$, with the addition of $0.007 \mathrm{M} \mathrm{L}$ cysteine, $0.006 \mathrm{M}$ ascorbate, $0.5 \%$ Tween- $80,4 \%$ polyvinylpyrrolidone, $0.5 \mathrm{M}$ saccharose (Tobolski, 1978). Enzymes were separated from crude homogenates by standard horizontal starch-gel electrophoresis (gel concentration $12 \%, w / v$ ). The compositons of electrode and gel buffers are shown in table I. Buffer formulations for enzyme stains were adapted from Cheliak et al (1984), Conkle et al (1982) and Vallejos (1983).

Six enzymes were analysed for the population survey. They corresponded to 6 encoding loci (table II). Mendelian inheritance of alleles was verified by means of segregation analyses in controlled crosses (unpublished data). Three enzymes are involved in primary metabolism, and the remaining 3 in secondary metabolism (respectively, groups I and II) (Bergmann, 1991).

Allelic frequencies were estimated within each population; observed and expected heterozygosities within populations were calculated according to Brown and Weir (1983). Parameters of gene differentiation between populations $\left(G_{\mathrm{st}}\right)$

Table I. Composition of buffers for starch-gel electrophoresis.

No Electrode bufferipH GelbufferipH Reference

$10.006 \mathrm{M}$ citric acid/7.0

2
Diluted electrode

buffer $(1: 20) / 7.0$
Clayton and

Tretiak, 1972

Scandalios, 1969 modified 


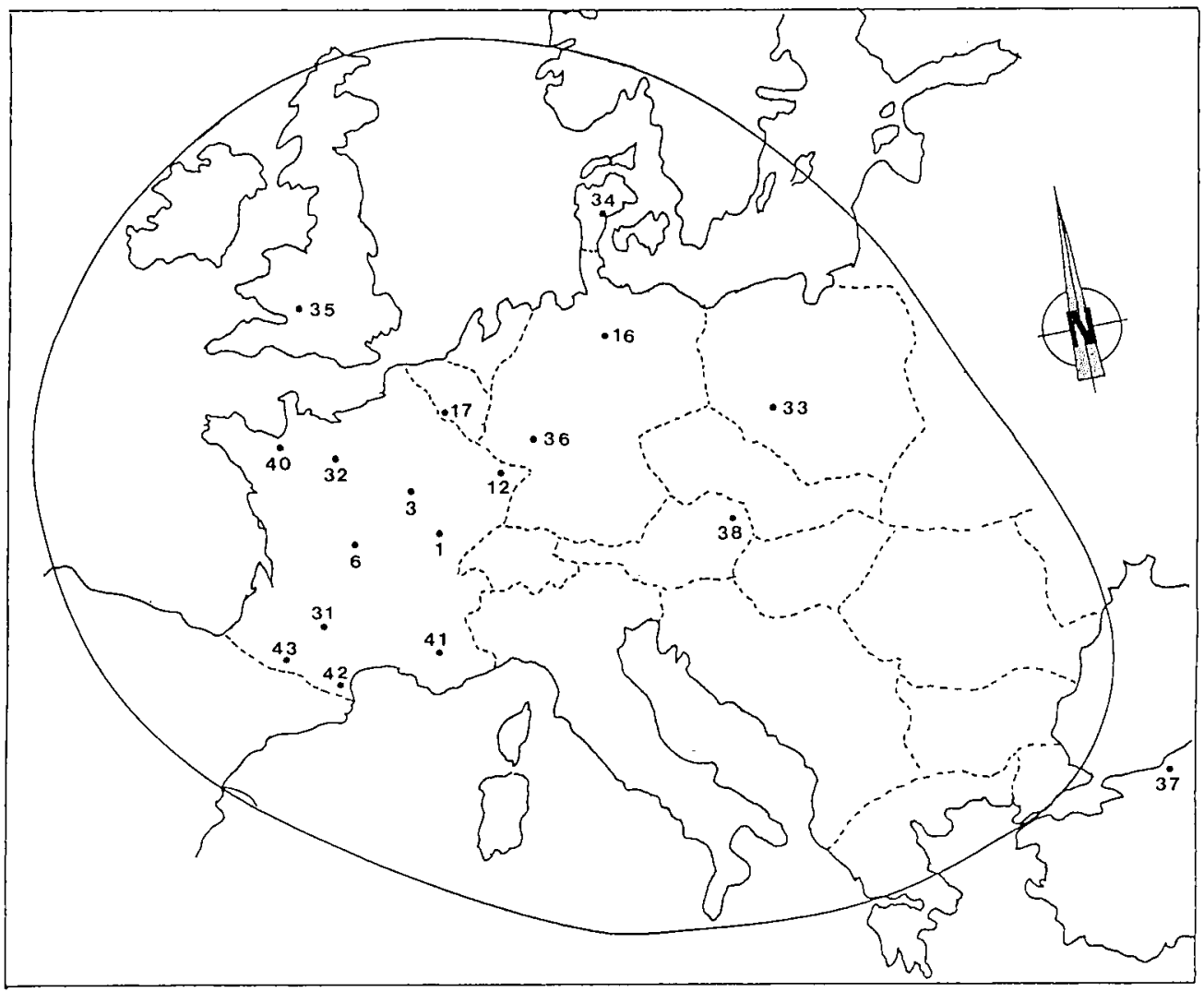

Fig 1. Map of the populations sampled in the natural range of Quercus petraea. The solid line corresponds to the limit of the natural distribution of $Q$ petraea.

were calculated with Nei's $(1973,1977)$ genetic diversity statistics. Confidence intervals of $G_{\mathrm{st}}$ were calculated by bootstrapping over populations (500 bootstrap samples) (Efron, 1979).

\section{RESULTS}

\section{Frequency profiles}

Frequency profiles differed markedly among the different loci. For the GOT lo- cus, the frequency of the most common allele was > 0.9; in the cases of the PGM, $P G I$ and $M R$ loci, it varied between 0.75 and 0.9 ; whereas for $A C P$ and DIA, it equalled 0.6. Clearly the difference in frequency profiles separated the 2 enzyme groups. The frequency profiles were consistent over all populations except for locus $A C P$. For example, in each population, the most common allele of GOT showed a frequency $>0.9$, ranging from 0.9 to 0.97 . However, despite this consistency, the alle- 
Table Il. Enzyme systems and structure, polymorphic loci and buffers used.

\begin{tabular}{llccc}
\hline $\begin{array}{l}\text { Enzyme (group, EC no) } \\
\text { a }\end{array}$ & Structure & SGE buffer ${ }^{\mathrm{b}}$ & Locus & Allele number \\
\hline $\begin{array}{l}\text { Acid phosphatase } \\
\text { (II, 3.1.3.2) }\end{array}$ & Monomeric & 1 & ACP & 5 \\
$\begin{array}{l}\text { Diaphorase } \\
\text { (II, 1.8.1.4) }\end{array}$ & Tetrameric & 2 & DIA & 5 \\
$\begin{array}{l}\text { Glutamic-oxalacetic transaminase } \\
\text { (I, 2.6.1.1) }\end{array}$ & Dimeric & 1 & GOT & 3 \\
$\begin{array}{l}\text { Menadione reductase } \\
\text { (II, 1.6.99.2) }\end{array}$ & Tetrameric & 1 & MR & 5 \\
$\begin{array}{l}\text { Phosphoglucoisomerase } \\
\text { (I, 5.3.1.9) }\end{array}$ & Dimeric & 2 & PGI & 5 \\
$\begin{array}{l}\text { Phosphoglucomutase } \\
\text { (I, 5.4.2.2) }\end{array}$ & Monomeric & 2 & PGM & 4 \\
\hline
\end{tabular}

a Enzyme group according to Bergmann (1991). ${ }^{0}$ Starch-gel electrophoretic buffer systems used (see table $)$.

c Number of alleles identified in the population surveyed.

lic frequency differences between populations were significant.

\section{Within-population genetic variation}

Enzymes of group II exhibited higher heterozygosities than enzymes of group I because of their different frequency profiles (table III).

There were important differences in levels of observed and expected heterozygosities among populations, particularly for enzymes of group I. In addition, there was a clear geographic pattern of variation of expected heterozigosity. Populations originating from the eastern part of the natural range $(12,16,17,33,34$ and 36$)$ exhibited lower levels of variation. In addition, populations from the south-western part of the range (41 and 43) showed similarly low heterozygosities compared to all other populations. Due to the large sample size per population (120 seeds), standard errors of heterozygosities were lower than 0.01 , indicating that the above-mentioned differences between western and eastern populations are significant. However, for enzymes of group II, the overall range of differences among populations was lower than in group I, and there was no apparent geographic trend of variation.

\section{Differentiation among populations}

Coefficients of gene differentiation $\left(G_{\mathrm{st}}\right)$ among populations were calculated for 2 different samples: 1) all populations, and 2) central populations only $(1,3,6,12,17$, 32 and 36). The choice of central populations was arbitrary. The main objective of 
Table III. Observed $\left(H_{0}\right)$ and expected heterozygosity $\left(H_{\theta}\right)$ in different populations.

\begin{tabular}{|c|c|c|c|c|c|c|}
\hline \multirow[t]{2}{*}{ Population } & \multicolumn{2}{|c|}{ Group I enzymes } & \multicolumn{2}{|c|}{ Group /I enzymes } & \multicolumn{2}{|c|}{ Total } \\
\hline & $\mathrm{H}_{o}$ & $\mathrm{H}_{e}$ & $\mathrm{H}_{0}$ & $\mathrm{H}_{e}$ & $\mathrm{H}_{0}$ & $\mathrm{H}_{\theta}$ \\
\hline Les Etangs (1) a & 0.221 & 0.242 & 0.458 & 0.462 & 0.340 & 0.352 \\
\hline Pontigny (3) & 0.310 & 0.310 & 0.448 & 0.482 & 0.379 & 0.396 \\
\hline Baumiers (6) & 0.193 & 0.269 & 0.445 & 0.510 & 0.320 & 0.389 \\
\hline St Jean (12) & 0.116 & 0.124 & 0.455 & 0.452 & 0.285 & 0.288 \\
\hline Kempelhorn (16) & 0.146 & 0.155 & 0.459 & 0.453 & 0.302 & 0.304 \\
\hline Chimay (17) & 0.194 & 0.188 & 0.454 & 0.442 & 0.324 & 0.315 \\
\hline Gresigne (31) & 0.194 & 0.185 & 0.479 & 0.505 & 0.337 & 0.345 \\
\hline Perseigne (32) & 0.253 & 0.255 & 0.379 & 0.426 & 0.316 & 0.340 \\
\hline Darnowiec (33) & 0.161 & 0.169 & 0.412 & 0.440 & 0.287 & 0.304 \\
\hline Londalnaes (34) & 0.145 & 0.157 & 0.447 & 0.542 & 0.296 & 0.350 \\
\hline Dymock (35) & 0.202 & 0.202 & 0.442 & 0.453 & 0.323 & 0.327 \\
\hline Elmstein (36) & 0.137 & 0.136 & 0.420 & 0.481 & 0.278 & 0.309 \\
\hline Bolu (37) & 0.212 & 0.279 & 0.289 & 0.332 & 0.254 & 0.305 \\
\hline Klostermarienberg (38) & 0.228 & 0.223 & 0.441 & 0.447 & 0.334 & 0.335 \\
\hline St Aubin (40) & 0.248 & 0.261 & 0.415 & 0.467 & 0.332 & 0.364 \\
\hline Vachéres (41) & 0.135 & 0.146 & 0.555 & 0.545 & 0.345 & 0.345 \\
\hline Bareilles (42) & 0.218 & 0.215 & 0.478 & 0.518 & 0.348 & 0.367 \\
\hline Planès (43) & 0.166 & 0.163 & 0.513 & 0.552 & 0.339 & 0.358 \\
\hline
\end{tabular}

a Numbers correspond to the locations indicated in figure 1.

this analysis was to separate the total sample of populations into 2 extreme geographic groups, in order to verify whether separation in space had resulted in genetic differentiation. Other combinations of 6-9 populations were created to form the central population group, but always excluding peripheral populations of the natural range. $G_{\text {st }}$ values were consistent over all the combinations. Therefore, only the results corresponding to one combination are presented here.

On the whole range basis, $G_{\text {st }}$ values vary between 0.02 and 0.05 , showing no significant difference between loci (table IV). However, in the central part of the natural range, group II enzymes showed lower differentiation than group I enzymes.
Differentiation increased significantly for group II enzymes when the sample of populations increased from the central to the whole range of distribution (table IV). The highest allelic frequency differences were found for locus ACP. In most populations, ACP had only 2 major alleles, each with a frequencies close to 0.5 . However, populations located at the edges of the distribution range $(33,35,37$ and 42 ) differed, with allele 1 having frequencies varying between 0.15 and 0.40 .

Bootstrapping enabled us to obtain the distribution of the $G_{\text {st }}$ values. For a given locus, there are striking differences in the overlap of the distribution of $G_{\mathrm{st}}$ values corresponding to the 2 samples of populations. The distributions overlap completely 
for group I enzymes, indicating no differences in levels of genetic differentiation. In contrast, there is only a reduced overlap for group II enzymes.

\section{DISCUSSION AND CONCLUSION}

Gene diversity in sessile oak populations clearly differs according to the class of allozymes studied. Enzymes involved in secondary metabolism exhibited higher withinpopulation variation than enzymes involved in primary metabolism. These discrepancies were due to differences in allelic frequency profiles rather than to the number of alleles. These observations confirm previous results found for other species when both groups of enzymes were compared (Bergmann, 1991).

We found a geographic pattern of variation of heterozygosity values for group I enzymes. Eastern and most southern populations exhibited lower levels of genetic variation. Similar results have been obtained from a larger number of loci in a survey of exclusively French populations (Kremer et al, 1991). Populations from northeastern France had lower heterozygosity values. Variations in population sizes may be the cause of these differences. Sessile oak is known to have extremely irregular and heterogeneous seed crops in northeastern France, Germany and more eastern European countries. Whereas along the Loire river a good crop occurs every 3 years, in northeastern France, bumper crops are extremely scarce. As a result, the density of fruiting trees is reduced in the eastern part of the range as compared to the western side. On the other hand, southern populations exhibiting low levels of genetic variation $(41,43)$ are located on the edges of the natural range, where sessile oaks occur only in isolated stands. Some of these stands may stem from a narrower genetic base, or even founder effects.

Genetic differentiation among stands is extremely low $\left(G_{\mathrm{st}}\right.$ values varied between 2 and $5 \%$, depending upon the locus). Reports on genetic differentiation in other range-wide studies of oaks provided similar conclusions (Schnabel and Hamrick, 1990 for $Q$ gambelii and $Q$ macrocarpa; Lumaret and Michaud, 1991 for $Q$ ilex). While life-history traits (gene flow and outcrossing) explain only part of the low population differentiation (Hamrick and Godt, 1990), the effects of evolutionary history are largely unknown. Sessile oak has been

Table IV. Between-population gene differentiation $\left(G_{\mathrm{st}}\right)$.

\begin{tabular}{|c|c|c|c|c|c|}
\hline \multirow{2}{*}{$\begin{array}{l}\text { Locus } \\
\text { group }\end{array}$} & \multicolumn{2}{|c|}{ Overall the entire range a } & \multicolumn{2}{|c|}{ Central part ${ }^{\mathrm{b}}$} & \multirow[t]{2}{*}{$\mathrm{B}^{\mathrm{c}}$} \\
\hline & $\mathrm{G}_{s t}$ & Confidence interval & $\mathrm{G}_{s t}$ & Confidence interval & \\
\hline $\mathrm{ACP}(\mathrm{II})$ & 0.045 & $(0.015-0.083)$ & 0.010 & $(0.001-0.025)$ & 0.12 \\
\hline DIA (II) & 0.036 & $(0.018-0.056)$ & 0.013 & $(0.005-0.026)$ & 0.15 \\
\hline GOT (I) & 0.027 & $(0.010-0.045)$ & 0.022 & $(0.002-0.060)$ & 1.00 \\
\hline MR (II) & 0.030 & $(0.016-0.046)$ & 0.014 & $(0.002-0.027)$ & 0.41 \\
\hline PGI (I) & 0.024 & $(0.011-0.042)$ & 0.025 & $(0.004-0.051)$ & 1.00 \\
\hline PGM (I) & 0.033 & $(0.013-0.052)$ & 0.035 & $(0.005-0.066)$ & 1.00 \\
\hline
\end{tabular}

a Total sample of populations. ${ }^{b}$ Populations from the central part of the range $(1,3,6,32,12,17$ and 36$) .{ }^{c} B$ is the proportion of bootstrap samples of a having $G_{\text {st }}$ values lower than the $2.5 \%$ highest values of ${ }^{b}$. 
restricted to southern Europe since the last glaciation. As a result, today's stands may originate from several glacial refugia. The multi-refugia hypothesis should result in higher gene differentiation between widely separated populations. Information from a larger set of loci is necessary to clarify post-glacial migration pathways.

$G_{\text {st }}$ values calculated in our study are similar to those found in regional studies on sessile oak (Kremer et al, 1991; MüllerStarck and Ziehe, 1991). However, our results clearly showed that only group I enzymes maintained the same level of differentiation, regardless of the origin of the sample populations: $G_{\mathrm{st}}$ values corresponding to the whole range did not differ from $G_{\text {st }}$ values calculated only for populations in the central part of the range. Group II enzymes tended to have increased levels of differentiation as the sampling range increased. Interestingly, these enzymes also showed the highest differentiation between closely related species ( $Q$ robur and $Q$ petraea; Kremer et al, 1991). The different levels of differentiation between the 2 enzyme groups may be related to their sensitivities to evolutionary forces. For group I enzymes, differentiation may result from a balance between genetic drift and gene flow, whereas natural selection may act as an additional force for group II enzymes.

\section{REFERENCES}

Bergmann $F$ (1991) Isozyme gene markers. In: Genetic Variation in European Populations of Forest Trees (Müller-Starck G, Ziehe M, eds). Sauerländers-Verlag, Frankfurt-amMain, 67-78

Brown AHD, Weir BS (1983) Measuring genetic variability in plant populations. In: Isozymes in Plant Genetics and Breeding, Part A (Tanksley SD, Orton TJ, eds) Elsevier Science Publ, Amsterdam, 219-239
Camus A (1934-1954) Les Chênes. Éditions Paul-Lechevalier, Paris, $1314 \mathrm{pp}$

Cheliak WM, Morgan K, Dancik BP, Strobeck C, Yeh FCH (1984) Segregation of allozymes in megagametophytes of viable seed from a natural population of Jack pine, Pinus banksiana Lamb. Theor App/ Genet 69, 145-151

Clayton JW, Tretiak DN (1972) Amine-citrate buffers for $\mathrm{pH}$ control in starch-gel electrophoresis. J Fish Res Board Can 29, 1169-1172

Conkle DT, Hodgkiss PD, Nunnally L, Hunter S (1982) Starch Gel Electrophoresis of Conifer Seeds: A Laboratory Manual. US Dept Agric Exp Stat, Gen Tech Rep PSW 64

Efron B (1979) Bootstrap methods: another look at the jacknife. Ann Stat 7, 1-26

Hamrick JL, Godt MJ (1990) Allozyme diversity in plant species. In: Plant Population Genetics, Breeding and Genetic Resources (Brown AH, Clegg MT, Kahler AL, Weir BS, eds) Sinauer Associates, Sunderland, MA, 23-42

Kleinschmit J (1993) Intraspecific variation of growth and adaptative traits in European oak species. Ann Sci For 50 (suppl 1), 166s-185s

Krahl-Urban J (1959) Die Eichen. Paul PareyVerlag, Hamburg, $288 \mathrm{pp}$

Kremer $A$, Petit $R$, Zanetto $A$, Fougère $V$, Ducousso A, Wagner D, Chauvin C (1991) Nuclear and organelle gene diversity in Quercus robur and $Q$ petraea. In: Genetic Variation in European Populations of Forest Trees (MüllerStarck G, Ziehe M, eds) Sauerländer's-Verlag, Frankfurt-am-Main, 141-166

Lumaret R, Michaud H (1991) Genetic variation in holm oak populations. In: Genetic Variation in European Populations of Forest Trees (Müller-Starck G, Ziehe M, eds) Sauerländer's Verlag, Frankfurt-am-Main, 167-172

Müller-Starck G, Ziehe M (1991) Genetic variation in populations of Fagus sylvatica $L$, Quercus robur L, and $Q$ petraea Liebl in Germany. In: Genetic Variation in European Populations of Forest Trees (Müller-Starck G, Ziehe $M$, eds) JD Sauerländer's-Verlag, Frankfurt-am-Main, 125-140

Nei M (1973) Analysis of gene diversity in subdivided populations. Proc Natl Acad Sci USA 12, 3321-3323

Nei $M(1977) F$ statistics and analysis of gene diversity in subdivided populations. Ann Hum Genet 41, 225-233 
Scandalios JG (1969) Genetic control of multiple molecular forms of enzymes in plants: a review. Biochem Genet 3, 37-79

Schnabel A, Hamrick JL (1990) Comparative analysis of population genetic structure in Quercus macrocarpa and $Q$ gambelii (Fagaceae). Syst Bot 15, 240-251

Tobolski JJ (1978) Isozyme variation in several species of oaks. In: Proceedings of the Central Hardwood Tree Improvement Con- ference. Purdue University, IN, USA, 456468

Vallejos CE (1983) Enzyme activity staining. In: Isozymes in Plant Genetics and Breeding, Part A (Tanksley SD, Orton TJ, eds) Elsevier Science Publ, Amsterdam, 469-515

Zanetto A (1989) Polymorphisme enzymatique du chêne sessile (Quercus petraea (Matt) Liebl) en France. DEA thesis, Université de Pau et des Pays de l'Adour, Pau, France, $42 p$ 